\title{
MENINGKATKAN KECERDASAN LINGUISTIK MELALUI MENDONGENG
}

\author{
Zulfitria $^{1}$; Neneng Fadhila ${ }^{2}$ \\ Teknologi Pendidikan Fakultas Ilmu Pendidikan, Universitas Muhammadiyah Jakarta ${ }^{12}$ \\ zulfitria81@gmail.com¹; fadhilahshisi@gmail.com²
}

\begin{abstract}
Storytelling is an interesting and fun method for early childhood who will learn to speak and communicate with the interlocutor. The reality that occurs in learning activities in Kindergarten is that many teachers still use monotonous methods in developing children's linguistic/language intelligence. The method used does not invite children to take an active role in every activity given by the teacher, children just sit at the table and listen to stories read by the teacher. The purpose of this study was to improve the linguistic intelligence of children in TK Tanah Tingal Ciputat. This type of research is classroom action research (CAR) with a working procedure of 2 (two) cycles consisting of four stages, namely planning, action implementation, observation, and reflection. The subjects of this study were the teacher and 11 children of group B TK Tanah Tingal Ciputat. The results of the study stated that using the storytelling method can improve the linguistic intelligence of children in TK Tanah Tingal Ciputat. As for the average increase in the percentage of children's linguistic intelligence from before the action until the second cycle, namely pre-cycle 18\%, cycle I reached $45 \%$, cycle II reached $82 \%$. This study concludes that there is an increase in children's linguistic intelligence with the storytelling method at Tanah Tingal Ciputat Kindergarten.Abstrak dibuat satu spasi maksimal 150 dalam Bahasa Inggris dan Bahasa Indonesia. [Effect of role-playing macro methods on children's speaking ability in group B in Nurul Rohmah Bekasi. This research is motivated by the lack of ability to speak to children. Data analysis techniques used were descriptive statistical analysis and nonparametric statistical analysis.
\end{abstract}

Keywords: early childhood, role-playing, speaking

\begin{abstract}
ABSTRAK
Mendongeng merupakan metode yang menarik dan menyenangkan bagi anak usia dini yang akan belajar berbahasa dan berkomunikasi dengan lawan bicaranya. Realitas yang terjadi dalam kegiatan belajar di Taman Kanak-kanak banyak guru yang masih menggunakan metode yang monoton dalam mengembangkan kecerdasan linguistik/berbahasa anak. Metode yang digunakan tidak mengajak untuk anak ikut peran aktif dalam setiap kegiatan yang diberikan guru, anak hanya duduk dimeja dan mendengarkan cerita yang dibacakan oleh guru. Tujuan penelitian ini adalah untuk meningkatkan kecerdasan linguistik anak di TK Tanah Tingal Ciputat. Jenis penelitian ini adalah penelitian tindakan kelas (PTK) dengan prosedur kerja 2 (dua) siklus terdiri dari empat tahap, yaitu perencanaan, pelaksanaan tindakan, observasi dan refleksi. Subyek penelitian ini adalah guru dan 11 anak kelompok B TK Tanah Tingal Ciputat. Hasil penelitian menyatakan bahwa dengan menggunakan metode mendongeng dapat meningkatkan kecerdasan linguistik anak di TK Tanah Tingal Ciputat. Adapun peningkatan rata-rata prosentase kecerdasan linguistik anak dari sebelum tindakan sampai dengan siklus II yakni pra siklus $18 \%$, siklus I mencapai $45 \%$, siklus II mencapai $82 \%$. Kesimpulan penelitian ini adalah adanya peningkatan terhadap kecerdasan linguistik anak dengan metode mendongeng di TK Tanah Tingal Ciputat.
\end{abstract}

Kata kunci: anak usia dini, bermain peran, berbicara

\section{PENDAHULUAN}

Undang-undang No. 20 Tahun 2003 tentang Sistem Pendidikan Nasional pasal 1 angka 14 menyatakan bahwa Pendidikan Anak Usia Dini (PAUD) adalah suatu upaya pembinaan yang ditunjukkan kepada anak sejak lahir sampai dengan usia enam tahun yang dilakukan melalui pemberian rangsangan pendidikan untuk membantu pertumbuhan dan perkembangan jasmani dan rohani agar anak memiliki kesiapan dalam memasuki pendidikan lebih lanjut yang 
diselenggarakan pada jalur formal, nonformal, dan informal (Diknas, 2010).

PAUD adalah investasi yang amat besar bagi keluarga dan bangsa. Anak- anak adalah generasi penerus keluarga dan sekaligus penerus bangsa, yang kelak membangun bangsa Indonesia menjadi bangsa yang maju, yang tidak ketinggalan dari bangsa-bangsa lain. Dengan kata lain, masa depan bangsa sangat ditentukan oleh pendidikan yang diberikan kepada anakanak. Oleh karena itu Pendidikan anak usia dini merupakan investasi bangsa yang sangat berharga dan sekaligus merupakan infrastruktur bagi pendidikan selanjutnya. Itulah sebabnya negara-negara maju sangat serius mengembangkan pendidikan anak usia dini (Suyanto, 2015).

Kecerdasan menurut masyarakat pada umumnya adalah hanya anak pintar dalam pembelajaran dan nilainya bagus dalam aspek perkembangan kognitifnya saja. Pada dasarnya setiap individu berbeda antara satu dengan yang lainnya masing-masing individu akan mempertahankan hidup dengan mengembangkan pengetahuan, sikap dan ketrampilan dengan cara yang berbeda pula, untuk itulah maka guru dan orang tua perlu memperlakukan masing-masing anak yang memang berbeda itu dengan memberikan kesempatan yang berbeda pula.

Pada masa usia dini tingkat kemampuan anak untuk menyerap informasi mencapai $80 \%$, dengan kata lain pada usia enam tahun ke atas sampai masa tua tingkat penyerapan informasi hanya sekitar $20 \%$ saja. Dengan alasan inilah dikatakan masa usia dini sebagai masa keemasan (golden age). Dibutuhkan berbagai macam stimulasi untuk mengembangkan berbagai aspek kecerdasan yang dimiliki anak pada usia dini. Salah satu aspek kecerdasan yang harus dikembangkan adalah kecerdasan linguistik.

Kecerdasan linguistik sudah harus diasah sejak usia dini karena merupakan alat bahasa yang digunakan manusia untuk berinteraksi dan berkomunikasi dengan individu yang lain. Perkembangan kecerdasan linguistik pada anak juga dipengaruhi oleh bagaimana anak memperoleh bahasa dari lingkungannya, yang tanpa disadarinya memberikan pemahaman berbahasa sehingga dapat menggunakan bahasa tersebut untuk berkomunikasi dengan orang lain.

Berdasarkan Permendikbud No: 137 Tahun 2014 disebutkan, dalam standar tingkat pencapaian perkembangan anak (STPPA) usia 5-6 tahun, pada aspek perkembangan bahasa atau kecerdasan linguistik khususnya lingkup perkembangan mengungkapkan bahasa adalah: menjawab pertanyaan yang lebih kompleks, berkomunikasi secara lisan, memiliki perbandaharaan kata, serta mengenal simbolsimbol untuk persiapan membaca, menulis, dan berhitung menyusun kalimat sederhana dalam struktur lengkap (pokok kalimat, predikat, keterangan), melanjutkan sebagian cerita/ dongeng yang telah diperdengarkan.

Berdasarkan dari uraian latar belakang yang telah dipaparkan di atas, maka dapat dirumuskan masalah penelitian ini sebagai berikut: Bagaimana upaya meningkatkan kecerdasan linguistik dalam metode mendongeng di TK kelompok B Tanah Tingal Ciputat Tahun Ajaran 2018-2019? 
Manfaat dalam meningkatkan kecerdasan linguistik dalam metode mendongeng di TK kelompok B Tanah Tingal Ciputat, yaitu:

1. Bagi Siswa: mendapatkan pembelajaran yang menyenangkan, bermakna, pengalaman baru dan wawasan dalam meningkatkan kemampuan mengungkapkan, menyimak, membaca, menulis dan berbicara.

2. Bagi Guru: menerapkan pembelajaran bercerita menggunakan bermacam-macam media, membangkitkan kreatifitas guru dalam menerapkan dan menciptakan inovasi dalam kegiatan pembelajaran, guru lebih cepat memahami kemampuan anak dalam hal mengungkapkan, menyimak, membaca, menulis dan berbicara.

3. Bagi Sekolah: Meningkatkan kreatifitas dalam mengembangkan Alat Permainan Edukatif (APE) dan mutu Pendidikan Anak Usia Dini melalui peningkatan prestasi anak dan kinerja guru.

\section{KAJIAN LITERATUR}

- HAKIKAT

METODE

\section{MENDONGENG}

Metode merupakan teknik atau cara yang harus dilalui untuk melakukan suatu pekerjaan dalam rangka mencapai suatu tujuan (Roestiyah,1998). Sedangkan menurut Saliwangi metode adalah cara yang dipilih untuk mencapai tujuan tertentu (Saliwangi,1994). Sehubungan dengan hal tersebut Sunaryo berpendapat bahwa metode adalah cara-cara yang ditempuh untuk mencapai suatu hasil yang memuaskan (Sunaryo,1995).

Kemajuan suatu negara atau bangsa yang cerdas pada hakikatnya dimulai dari pengembangan di bidang pendidikan. Dalam kaitan ini, Suradika (2009) menyatakan bahwa kemajuan suatu negara dan kesejahteraan rakyatnya berbanding lurus dengan tingkat kualitas pendidikan negara tersebut. Negara-negara yang memiliki kualitas pendidikan tinggi memiliki kecenderungan tinggi pula kemajuan pembangunan dan kesejahteraan rakyatnya, demikian sebaliknya.

Inti dari pendidikan adalah membaca. Islam memberikan jalan kemajuan dengan membaca sebagaimana firman Allah SWT yaitu:

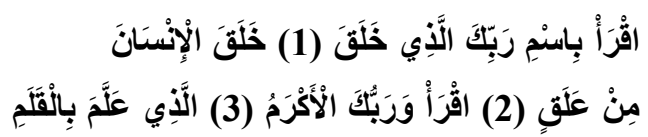
(4)

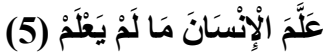

Artinya: "Bacalah dengan (menyebut) nama Tuhan-mu yang menciptakan, Dia telah menciptakan manusia dari segumpal darah. Bacalah, dan Tuhanmu-lah Yang Maha mulia, Yang mengajar (manusia) dengan pena, Dia mengajar manusia apa yang tidak diketahuinya” (Depag: 1997).

Dalam ayat tersebut Allah SWT telah mengisyaratkan kepada seluruh umat manusia untuk banyak belajar berbagai hal untuk dapat membaca tanda-tanda kekuasaan Allah SWT dengan aktivitas membaca.

Membaca merupakan jendela dunia. Membaca sangat penting dilakukan bagi orang yang suka mendongeng. Di era millennium ini, aktivitas mendongeng sudah jarang dilakukan orangtua terhadap anakanak. Malah sebaliknya anak lebih senang bermain games ataupun handphone 
dibandingkan membaca (Zulfitria, dkk, 2020).

Ada beberapa metode pembelajaran yang dapat digunakan dalam kegiatan pembelajaran bagi anak usia dini antara lain: tanya jawab, mendongeng (bercerita), bernyanyi, bermain peran (simulasi), eksplorasi (proyek), observasi, demonstrasi, karyawisata, praktek, kerja kelompok, diskusi, pemberian tugas.

Hal penting yang harus diperhatikan pendidik bahwa pemilihan metode dalam pembelajaran anak usia dini ini harus didasari oleh pemahaman yang benar mengenai anak usia dini berikut ini: setiap anak unik dan berbeda dengan yang lain, anak memiliki dunianva sendiri, dunia bermain dan bercerita, anak berhak mengekspresikan keinginannya, berhak mencoba dan melakukan kesalahan, beri kesempatan untuk berksplorasi dengan lingkungan sekitarnya, anak membutuhkan rasa aman.

Menurut Poerwadarminto (1955), dongeng adalah cerita, terutama tentang kejadian zaman dahulu, yang aneh-aneh atau cerita yang tidak benar-benar terjadi.

Dongeng berpotensi memberikan sumbangsih besar bagi anak untuk memiliki jati diri yang jelas dan pribadi yang berkarakter. Dongeng dapat digunakan sebagai sarana untuk mewariskan nilai-nilai luhur kepribadian. Secara umum dongeng dapat membantu anak menjalani masa tumbuh kembangnya. Anak-anak dapat memahami pola drama kehidupan melalui tokoh dongeng. Melalui dongeng, anak-anak akan terlibat dalam alur cerita. Dalam hal ini, anak-anak menumbuhkembangkan intelektualitasnya (Zulfitria, dkk: 2020).
Menurut Wiliam R. Bascom bahwa cerita rakyat dapat dibagi menjadi tiga golongan besar, yaitu (1) mite (myth), (2) legenda (legend), dan (3) dongeng (Folktale). Dongeng adalah cerita prosa rakyat yang tidak dianggap benar-benar terjadi oleh yang empunya cerita dan dongeng tidak terikat oleh waktu maupun tempat. James Danandjaja berpendapat bahwa kata dongeng menurut pengertian yang sempit adalah cerita pendek kolektif kesusastraan lisan, sedangkan pengertian dongeng dalam arti luas adalah cerita prosa rakyat yang tidak dianggap benar-benar terjadi (Danandjaja,1996).

Dongeng diceritakan terutama untuk hiburan walaupun banyak juga melukiskan kebenaran, berisikan pelajaran (moral) bahkan sindiran. Jadi, dongeng adalah cerita prosa rakyat yang dianggap benar-benar terjadi dan tidak terikat oleh waktu maupun tempat, yang mempunyai keguanaan sebagai alat hiburan atau pelipur lara dan sebagai alat pendidik (pelajaran moral).

Hal ini disebabkan oleh kemasan dongeng yang merupakan perpaduan antara unsur hiburan dengan pendidikan. Unsur pendidikan ditujukan melalui pesan yang dimuat, baik melalui cerita yang terakhir dengan kebahagiaan maupun kesedihan. Inti dari sebuah dongeng dapat dijadikan bahan perenungan bagi audiensinya. Tujuan metode bercerita atau mendongeng bagi anak usia 56 tahun adalah agar anak mampu mendengarkan dengan seksama terhadap apa yang disampaikan orang lain, anak akan bertanya apabila ia tidak memahaminya, akan dapat menjawab pertanyaan, anak dapat menceritakan dan mengekspresikan apa yang 
didengarkan dan diceritakannya pada orang lain, sehingga hikmah dari isi cerita dapat dipahami dan lambat laun didengarkan, diperhatikan, dilaksanakan, dan diceritakannya pada orang lain (Tampubolon,1991).

Dongeng berpengaruh besar pada perkembangan kemampuan berbahasa anak. Dongeng adalah kegiatan yang sangat bermanfaat bagi pengembangan otak anak. Dongeng dapat mengasah daya pikir dan imajinasi anak, meningkatkan kemampuan mengungkapkan bahasa dan berkomunikasi, membangun karakter anak, menghangatkan hubungan orangtua dan anak, guru dan peserta didik (Jasmine,2011).

\section{- HAKEKAT \\ LINGUISTIK}

KECERDASAN

Kecerdasan merupakan salah satu anugerah besar dari Tuhan kepada manusia dan menjadikannya sebagai salah satu kelebihan manusia dibandingkan dengan makhluk lainnya. Dengan kecerdasannya, manusia dapat terus menerus mempertahankan dan meningkatkan kualitas hidupnya yang semakin kompleks, melalui proses berfikir dan belajar secara terus menerus (Kosasi\& Dede, 2013).

Pengembangan kecerdasan siswa haruslah dilihat berdasarkan perbedaan kebutuhan terhadap tipe kemampuan yang dominan pada siswa. (Zulfitria, 2018)

Satu di antara tipe kecerdasan yang penting adalah kecerdasan linguistic. kecerdasan linguistik adalah kemampuan menggunakan kata-kata secara efektif, baik memengaruhi maupun memanipulasi. Dalam kehidupan sehari-hari kecerdasan linguistik bermanfaat untuk berbicara, mendengarkan, membaca dan menulis (Siswanto dan Lestari. 2012).

Kemampuan Kecerdasan linguistic pada anak sangat penting dikembangkan guna memperoleh kesiapan dalam mengikuti pembelajaran yang lebih tinggi, khususnya dalam pencapaian lingkup perkembangan kecerdasan linguistik yaitu dalam mengungkapkan bahasa.

Pembelajaran untuk meningkatkan kecerdasan linguistik dalam pengungkapan bahasa diberikan melalui pemberian stimulus/rangsangan dengan menggunakan metode, strategi, serta media yang tepat sehingga dapat meningkat dengan optimal.

Pengungkapan bahasa telah dikembangkan di TK Tanah Tingal Ciputat, ternyata faktanya disekolah tersebut hasilnya masih rendah, dan dapat dilihat dari kegiatan sehari-hari ketika anak-anak melakukan proses pembelajaran selama didalam kelas. Peneliti menemukan beberapa permasalahan antara lain: anak belum berkembang dalam hal kecerdasan linguistic yaitu diantaranya mengungkapkan bahasa disebabkan karena kurangnya media pembelajaran untuk anak.

Pada umumnya anak belum mau menjawab pertanyaan yang lebih kompleks ketika guru mengajukan pertanyaan karena kurangnya perbendaharaaa kata, anak belum mampu mengungkapkan keinginan, perasaan dan pendapat dengan kalimat sederhana ketika berkomunikasi dengan orang lain, anak belum mampu menyusun kalimat sederhana dalam struktur lengkap ketika guru meminta untuk menulis nama sendiri dan membuat kalimat sederhana, anak belum mampu menceritakan kembali cerita/dongeng yang telah diperdengarkan 
karena kesulitan untuk menyusun kalimat dengan jelas.

Kegiatan pembelajaran untuk meningkatkan kecerdasan linguistik yaitu dalam kemampuan mengungkapkan bahasa yang dilakukan di TK Tanah Tingal Ciputat masih kurang bervariasi karena hanya menggunakan media buku cerita bergambar dan kartu huruf saja, juga bahasa tubuh guru yang masih kaku atau belum luwes, penyajian pembelajaran yang kurang menarik. Akibatnya guru belum mampu menguasai kelas, sehingga peserta didik kurang bersemangat, cenderung bosan, tidak fokus dengan kegiatan yang diberikan dan pada akhirnya proses kegiatan belajar mengajar khususnya kecerdasan linguistik anak dalam pengungkapan bahasa anak menjadi terhambat dan kurang maksimal. Guru mempunyai peran yang sangat besar dalam proses.

Kegiatan Belajar Mengajar (KBM) dan diharapkan dapat menggunakan metode maupun media pembelajaran yang tepat dalam setiap kegiatannya. Kegiatan pembelajaran mengungkapkan bahasa di TK Tanah Tingal sebaiknya dilakukan melalui kegiatan yang menarik, menyenangkan, bervariasi dan kreatif. Perencanaan sumber belajar yang dilakukan oleh guru akan memberikan manfaat apabila guru dapat menyiapkan dan memilih sumber belajar yang sesuai dengan karakteristik, minat dan tujuan pembelajaran anak yang hendak dicapai.

Kecerdasan linguistik dalam kemampuan mengungkapkan bahasa dapat dikuasai oleh anak apabila dikembangkan dengan berbagai metode salah satunya dengan bercerita menggunakan alat peraga, dalam kesempatan ini peneliti menuturkan sesuatu yang mengisahkan tentang perbuatan atau sesuatu kejadian dengan tujuan membagikan pengalaman dan pengetahuan pada orang lain, agar metode dongeng dapat menarik perhatian anak maka digunakan media seperti gambar seri, boneka tangan, dan sebagainya.

Dengan metode dongeng menggunakan media gambar seri dan boneka tangan anak-anak dapat tertarik untuk berpartisipasi secara aktif dalam kegiatan, sehingga kecerdasan linguistik dalam kemampuan mengungkapkan bahasa anak akan berkembang secara optimal.

\section{METODE PENELITIAN}

Jenis penelitian kualitatif dengan penelitian tindakan kelas. Penelitian tindakan kelas merupakan suatu pencermatan terhadap kegiatan belajar berupa sebuah tindakan, yang sengaja dimunculkan dan terjadi dalam sebuah kelas secara bersama (Arikunto, 2014). Dalam penelitian ini variable yang diteliti adalah meningkatkan kecerdasan linguistik anak melalui metode mendongeng.

Tempat yang digunakan sebagai penelitian adalah Tanah Tingal yang berlokasi Jalan Merpati Raya No. 32 B Kelurahan Sawah Baru Kecamatan Ciputat Kota Tangerang Selatan Provinsi Banten. Subjek dalam penelitian ini adalah anak usia 5-6 tahun, anak sebagai pihak penerima tindakan berjumlah 11 anak terdiri dari 7 anak laki-laki dan 4 anak perempuan, peneliti sebagai pemberi tindakan. Waktu penelitian dilakukan dari tanggal 01 Oktober sampai 03 Desember 2018. 
Secara garis besar terdapat empat langkah dalam rancangan penelitian tindakan, yaitu: perencanaan, pelaksanaan, pengamatan, dan refleksi (Suharsimi Arikunto,2010).

Rencana siklus PTK dapat dilihat pada gambar spiral PTK Pendekatan penelitian ini adalah pendekatan kuantitatif. Dipilihnya pendekatan ini karena secara epistemologi penelitian ini memadukan dua sumber ilmu, yaitu (a) pemikiran rasional, dan (b) data empiris.

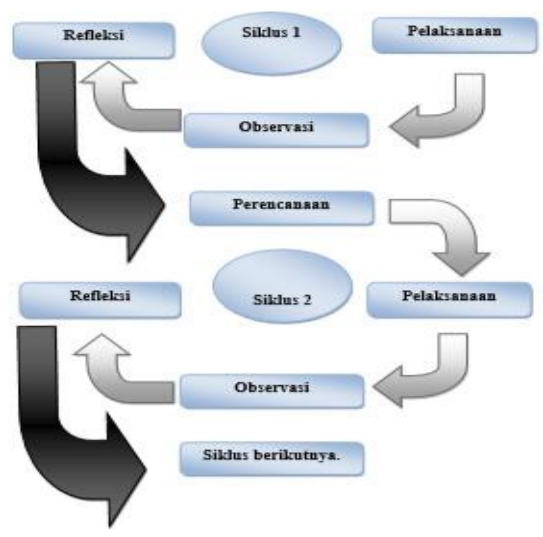

Gambar 5 Rencana siklus PTK

\section{PEMBAHASAN}

Data yang dikumpulkan adalah data peningkatan kecerdasan linguistik anak kelompok B melalui metode mendongeng yang diperoleh dengan teknik observasi terhadap indikator pencapaian perkembangan anak, yaitu pada aspek perkembangan bahasa atau kecerdasan linguistik khususnya lingkup perkembangan mengungkapkan bahasa dan beberapa indikator pencapaian perkembangan yang harus dicapai oleh anak dikelompok B usia 5-6 tahun untuk meningkatkan kecerdasan linguistik.

Tindakan yang dilakukan dalam penelitian ini dengan gambaran sebagai berikut: Berdasarkan indikator pencapaian perkembangan anak yang digunakan sabagai standar untuk melakukan observasi pada kelompok B usia 5-6 tahun yang berjumlah 11 anak, dapat dilihat pada tabel hasil evaluasi anak pada semester ganjil adalah sebagai berikut:

Tabel 5 Pra Siklus Kecerdasan Linguistik

\begin{tabular}{|c|c|c|}
\hline $\begin{array}{c}\text { Tahap } \\
\text { Perkembangan } \\
\text { Anak }\end{array}$ & $\begin{array}{c}\text { Jumlah } \\
\text { Anak }\end{array}$ & Presentase \\
\hline BB & 3 & $27 \%$ \\
\hline MB & 4 & $37 \%$ \\
\hline BSH & 2 & $18 \%$ \\
\hline BSB & 2 & $18 \%$ \\
\hline Jumlah & 11 & $100 \%$ \\
\hline
\end{tabular}

Keterangan:

$\mathrm{BB}=$ Belum Berkembang

$\mathrm{MB}=$ Mulai Berkembang

$\mathrm{BSH}=$ Berkembang Sesuai Harapan

Metode dongeng yang di lakukan dalam siklus I ini berjudul "Burung sang penolong dan kupu-kupu yang rajin", dengan tokoh dalam dongeng kupu-kupu yang rajin adalah: kupu-kupu dan jangkrik dan tokoh dalam dongeng burung sang penolong adalah burung, kupu-kupu dan lebah. Guru mengupayakan agar anak-anak merasa senang, mendengarkan, berkomunikasi, menyimak, memahami sesuai dengan cerita yang telah di sampaikan oleh guru. Siklus pertama dilakukan sebanyak 2 kali pertemuan dengan alokasi waktu 60 menit setiap pertemuannya.

Pelaksanaan penelitian pada siklus pertama di lakukan pada hari Senin 01 
Oktober dan hari Kamis 11 Oktober 2019, sesuai dengan RPPH yang telah di buat. Peneliti menggunakan metode mendongeng dalam KBM selama selama 60 menit, dengan metode dongeng yang berjudul burung sang penolong. Pendidik pada siklus pertama tidak menggunakan alat peraga.

Tabel 6 Kecerdasan Linguistik melalui metode mendongeng siklus I

\begin{tabular}{|c|c|c|}
\hline $\begin{array}{c}\text { Tahap } \\
\text { Perkembangan } \\
\text { Anak }\end{array}$ & $\begin{array}{c}\text { Jumlah } \\
\text { Anak }\end{array}$ & Presentase \\
\hline BB & 1 & $10 \%$ \\
\hline MB & 1 & $10 \%$ \\
\hline BSH & 4 & $37 \%$ \\
\hline BSB & 5 & $45 \%$ \\
\hline Jumlah & 11 & $100 \%$ \\
\hline
\end{tabular}

Setelah peneliti melakukan siklus I dari 11 anak terdapat 5 anak yang masuk kategori berkembang sangat baik, 4 anak yang masuk kategori berkembang sesuai harapan, 1 anak baru mulai berkembang, 1 anak belum berkembang. Sehingga perlu adanya siklus yang kedua dalam meningkatkan kecerdasan linguistik di TK Tanah Tingal Ciputat melalui metode mendongeng sehingga kecerdasan linguistik anak akan meningkat sangat baik.

Tindakan siklus Pertemuan pertama mendongeng dengan judul perkembang biakan ayam, peneliti menggunakan alat peraga gambar seri dari telur, ayam menetas, anak ayam dan asampai ayam dewasa dan peneliti bercerita dengan ekspresif.
Pertemuan kedua mendongeng dengan judul bebek yang baikk hati, peneliti menggunakan alat peraga boneka tangan bebek, ayam dan sapi dan peneliti mendongeng dengan ekspresif.

Pelaksanaan penelitian pada siklus kedua dilakukan di hari Senin 05 November dan Kamis 15 November 2018, sesuai dengan RPPH yang telah di buat. Peneliti menggunakan metode mendongeng dalam KBM selama 60 menit dengan menggunakan alat peraga seperti boneka tangan, buku cerita, gambar bebek, sapi dan ayam jago berserta tulisannya.

Tabel 7 Peningkatan Kecerdasan Linguistik melalui metode mendongeng siklus II

\begin{tabular}{|c|c|c|}
\hline $\begin{array}{c}\text { Tahap } \\
\text { Perkembangan } \\
\text { Anak }\end{array}$ & $\begin{array}{c}\text { Jumlah } \\
\text { Anak }\end{array}$ & Presentase \\
\hline BB & & \\
\hline MB & & \\
\hline BSH & 2 & $18 \%$ \\
\hline BSB & 9 & $82 \%$ \\
\hline Jumlah & 11 & $100 \%$ \\
\hline
\end{tabular}

Setelah peneliti melakukan siklus II dari 11 anak terdapat 9 anak yang masuk kategori berkembang sangat baik, 2 anak yang masuk kategori berkembang sesuai harapan dalam meningkatkan kecerdasan linguistik di TK Tanah Tingal Ciputat melalui metode mendongeng. Dari siklus kedua ini adanya peningkatan kecerdasan linguistik anak kelompok B melalui metode 
mendongeng dengan menggunakan alat (gambar seri dan boneka tangan).

\section{PENUTUP}

Berdasarkan hasil penelitian dan pembahasan dapat disimpulkan bahwa pembelajaran melalui bermain menggunakan metode dongeng tanpa alat dan dengan alat dapat meningkatkan kecerdasan linguistik pada anak kelompok B di TK Tanah Tingal Ciputat. Peningkatan tersebut dapat dilihat dari adanya peningkatan persentase dari Siklus I kriteria Belum Berkembang (BB) $10 \%$, Mulai Berkembang (MB) $10 \%$, Berkembang Sesuai Harapan (BSH) $37 \%$, Berkembang Sangat Baik (BSB) 45\%. Pada siklus II, Belum Berkembang (BB) 0\%, Mulai Berkembang (MB) 0\%, Berkembang Sesuai Harapan (BSH) 18\%, Berkembang sangat baik (BSB) $82 \%$.

Berdasarkan indikator yang ingin dicapai yaitu "Menjawab pertanyaan sesuai isi pertanyaan dengan benar, mengungkapkan keinginan, perasaan, pendapat melalui kalimat sederhana dengan tepat, membuat kalimat sederhana dengan struktur lengkap dan menceritakan kembali isi cerita secara sederhana dengan bahasa yang jelas" sudah mengalami peningkatan yang signifikan dan berkembang sesuai harapan, dapat dibuktikan dengan antusiasnya anak-anak selama mengikuti proses pembelajaran yang berlangsung dengan menggunakan metode mendongeng.

Secara proses, anak menjadi lebih aktif dari biasanya, ditandai dengan keaktifan anak saat menjawab pertanyaan, berani bertanya terkait hal yang belum mereka pahami, anak tidak malu lagi dan lebih percaya diri tampil didepan kelas dan anak senang berpatisipasi dalam pembelajaran.

\section{REFERENSI}

Arikunto, Suharsimi. 2014. "Penelitian Tindakan Kelas”. Jalkarta: PT Bumi Aksara.

Departemen Agama. 1997. Al-Qur'an dan Terjemahannya. Jakarta: Surya Cipta Aksara, h.597

Danandjaja, James. 1996. Cerita rakyat. Yogyakarta: Andi.

Diknas. 2007. Pengembangan Bakat Non Akademik. Jakarta: Depdiknas.

Igrea Siswanto dan Sri Lestari,. 2021. Panduan Bagi Guru dan Orangtua Pembelajaran Atraktif dan 100 Permainan Kreatif untuk PAUD, Yogyakarta: Andi.

Jasmin, Hana. 2011. Terapi Kecerdasan Anak Dengan Dongeng. Yogyakarta: Berlian Media.

Nandang Kosasih \& Dede Sumarna. 2013. Pembelajaran Quantum dan Optimalisasi Kecerdasan. Bandung: Alfabeta.

Poerwadarminta.1995. Kamus Umum Bahasa Indonesia. Jakarta: Balai Pustaka.

Roestiyah. 1998. Strategi Belajar Mengajar. Jakarta: Rineka Cipta.

Suyanto, Slamet. 2005. Konsep Dasar Pendidikan Anak Usia Dini. Jakarta: Depeartemen Pendidikan Nasional.

Saliwangi. 1994. Pendidikan Bahasa dan Sastra. Jakarta: Rineka Cipta. 
Sunaryo. 1995. Berbicara Sebagai Suatu Keterampilan Berbahasa. Bandung: FKSS - IKIP.

Suradika, Agus. 2009. Jalan Terjal Menuju Pendidikan Berkualitas: Sebuah Analisis Ekonomi Politik Pendidikan Indonesia. Orasi ilmiah pada acara wisuda sarjana dan pascasarjana Sekolah Tinggi Manajemen (STIMA) IMMI Jakarta.

Tampubolon, 1991. Mengembangkan Minat dan Kebiasaan Membaca Pada Anak, Bandung: Angkasa.

Zulfitria. Arif, Zainal. Abidah. Arifah. 2020.
Karakter Islami Anak. Jurnal Rausyan Fikr. Vol. 16 No. 2 September 2020. ISSN. 1979-0074 e-ISSN. 9772580 594187. Hal 67-73.

Zulfitria, Dewi, Happy Indira. Khanza, Meutia. dkk. 2020. Penerapan Pembelajaran Dongeng Dalam Membentuk Karakter Siswa.

Zulfitria, Kartikasari, Pratiwi. 2018. Pemanfaatan Media Belajar Untuk Meningkatkan Kemampuan Kecerdasan Visual Spasial Siswa Autis. PROSIDING SNTP, 2018 pkm.uika-bogor.ac.id

Dongeng Dalam Membentuk 